\title{
ДО ВИТОКІВ СТАНОВЛЕННЯ МІСЬКОГО ПРОМИСЛОВОГО МУЗЕЮ У ЛЬВОВІ
}

\begin{abstract}
У дослідженні на основі архівних джерел і наукових публікацій виокремлено коло питань, пов'язаних з історією становлення і розвитку міського промислового музею наприкіниі XIX-початку XX ст., визначено напрями його діяльності. 3'ясовано, щзо створення музею мало на меті шляхом комплектування і систематизації зразків продукції значної мистецької та наукової цінності сприяти вдосконаленню у краї технологій виготовлення та естетики промислових і ремісничих виробів.

Зростання інтересу громадськості й збільшення обсягу роботи працівників музею у статті продемонстровано динамікою відвідування Промислового музею у 1904-1908 роках. Розглянуто детальну інформацію про функціональні обов'язки та напрями діяльності працівників музею: залучення до роботи бібліотеки, закупівля збірок, створення тимчасових виставок, співучасть у публічних лекиіях. Висвітлено інформацію про тогочасне розуміння музейними працівниками необхіднсті вдосконалення професійних якостей працівників, залучених до роботи у бібліотеиі і з музейними збірками.

Підкреслено важливість публічної діяльності музею, його позитивний вплив у сфері популяризації промислу краю. Так, трунтовні наукові доробки музею, а саме видання «Взори промислу домамнього на Руси», збірники «Художній промисел» та окремі публікаџї з музейних збірок, мали на меті представити промислові вироби, виготовлені у краї, а також популяризувати музей у Галичині і за кордоном. Підкреслено важливу роль музею, окрім виставкової і просвітницької діяльності, у розвитку промислового шкільництва краю. Актуалізовано важливе значення школи рисунку і моделювання, яка діяла при міському Промисловому музеї для перепідготовки ремісників.

У статті проаналізовано визначну роль у діяльності Міського промислового музею відомого украӥнського етнографа і громадського діяча В. Шухевича. Розглянуто етнографічну й музейну діяльність В. Шухевича, зазначено про його діяльність як члена Надзірної ради Міського промислового музею, а також грунтовний внесок у підготовку десятитомного видання Промислового музею «Взори домашнього промислу на Руси» (1880-1889), яке стало однією із вдалих спроб дослідження українського народного мистецтва. 3 'ясовано значення історичного досвіду становлення і діяльності міського Промислового музею як надбання украӥнського та європейського музейництвв.
\end{abstract}

Ключові слова: Міський промисловий музей, музейні предмети, етнографічна, виставкова і просвітницька діяльність, промислове шкільництво.

Polina VERBYTSKA, orcid.org/0000-0003-3123-0768 Doctor of Pedagogical Science, Professor, Professor at the Department of History, Museum Studies and Cultural Heritage Lviv National Polytechnic University (Lviv,Ukraine) polinaverbytska@gmail.com

\section{TO THE ORIGINS OF THE ESTABLISHMENT OF THE CITY INDUSTRIAL MUSEUM IN LVIV}

The study, based on archival sources and scientific publications identifies a number of issues related to the history of the formation and development of the city's industrial museum in the late $19^{\text {th }}$ - and early $20^{\text {th }}$-century. It was found that the purpose of the museum was to promote the improvement of manufacturing and aesthetics of industrial and handicraft products in the region by collecting and systematizing samples of products of significant artistic and scientific value.

The growth of public interest and the increase in the volume of work of the museum staff is demonstrated in the article by the dynamics of visiting the Industrial Museum in 1904-1908. Detailed information on the functional responsibilities and activities of the museum staff is considered, in particular the involvement in the work of the library, purchase of collections, creation of temporary exhibitions and participation in public lectures. Especially, the article emphasized 
the importance of public activity of the museum and a positive influence in the field of popularization of industrial and handcraft products of the region.

In particular, the thorough scientific works of the museum - the publication "Samples of home craft in Russia" and some publications from museum collections were aimed at presenting industrial products made in the region, as well as to promote the museum in Halychyna and abroad. The article emphasizes the important role of the museum in the development of industrial professional schooling in the region, in addition to exhibition and educational activities. It was actualized the importance of the school of drawing and modeling for retraining of craftsmen, which operated at the city Industrial Museum.

The article analyzes the significant role of the famous Ukrainian ethnographer and public figure V. Shuchevych in the City Industrial Museum development. In particular, the article notes his participation as a member of the Supervisory Board of the City Industrial Museum as well as his thorough contribution to the preparation of the ten-volume edition of the Industrial Museum "Patterns of Home Craft in Russia" (1880-1889), which was one of the successful attempts to examine the Ukrainian folk art. This research clarifies the significance of the historical experience of formation and performance of the city Industrial Museum as a heritage of Ukrainian and European museology.

Key words: city industrial museum, museum objects, ethnographic, exhibition and educational activities, industrial schooling.

Постановка проблеми. У контексті політичних змін в Австро-Угорщині у другій половині XIX століття, зокрема проголошення конституції й автономії Галичини із власним сеймом, відбувався потужний розвиток економічного, наукового і культурного життя Львова як столиці коронного краю. Ці зміни позитивно вплинули на зростання інтересу галицького суспільства до історичної і культурної спадщини краю, а також сприяли колекціонуванню різних культурних артефактів. Саме приватні збірки цінних предметів і заклали основи міських музеїв, які виникли наприкінці XIX ст. у Львові. Таким чином на початку 70-х років XIX ст. започаткувався один із провідних музейних осередків Галичини - Міський промисловий музей, який мав на меті сприяння розвитку народних художніх промислів.

Аналіз досліджень. Становлення і розвиток музейної справи в Галичині наприкінці XIX початку XX ст. досліджували українські й польські історики. Окрім наукових розвідок українських науковців Л. Федорової, М. Голубця, Ю. Гошко, присвячених дослідженню історичних витоків Міського промислового музею, не досить вивченими в українській історіографії залишаються різні аспекти його розвитку й діяльності.

Внесок В. Шухевича в організацію українського музейництва Східної Галичини був предметом дослідження науковців П. Арсенича, А. Карпенка, Г. Скрипник, О. Сапеляк, І. Головацького, А. Данилюка, В. Кушніра, О. Сілецької та низки інших дослідників. Проте роль відомого українського етнографа у функціонуванні Промислового музею Львова мало представлена у наукових розвідках.

Мета статті - висвітлення особливостей становлення та розвитку Міського промислового музею у Львові наприкінці XIX - початку XX ст. і йогороль удіяльності ВолодимираШухевича,відомого українського етнографа і громадського діяча.
Виклад основного матеріалу. Джерелознавчою базою дослідження $є$ архівні документи із зібрань Центрального державного історичного архіву України (далі - ЦДІАУ) у м. Львові, зокрема матеріали фонду 735 «Володимир Шухевич етнограф», опису 1 справи 5 «Шухевич Володимир, український громадський діяч». Документи справи містять інформацію про етнографічну діяльність В. Шухевича, розкривають зміст його приватної переписки із відомими науковцями, етнографами й громадськими діячами, товариством «Просвіта» у м. Львові. У цій справі також представлені свідчення офіційної переписки адміністрації Промислового музею із магістратом міста щодо забезпечення його функціонування.

У відділі рукописів Львівської національної наукової бібліотеки України ім. В. Стефаника зберігається особистий архівний фонд Леопольда Райса (1889-1944) - відомого архітектора та збирача матеріалів до історії Львова (фонд № 92). Колекція зібраних Л. Райсом матеріалів до історії Львова (1637-1939) - це здебільшого оригінали і копії офіційних документів державних установ і громадських організацій, об'єднаних у предметно-тематичні рубрики, серед яких є матеріали, пов'язані 3 діяльністю міського Промислового музею. Зокрема, у справі 6 «Міський промисловий музей» зберігаються документи до історії музею за 1881-1912 роки.

Беручи до уваги фрагментарний характер архівних матеріалів, аналіз проблеми дослідження здійснено також на основі опрацювання наукових праць, присвячених розвитку музейної справи у Львові в досліджуваний період, а також діяльності її відомих натхненників. Одним зі шляхів поліпшення економічного становища краю, як зазначив Скрипник (1989), вважалося розширення виробництва та піднесення якості продукції із місцевої сировини на базі традиційних 
кустарних промислів. 3 цією метою влаштовувалися численні промислові та сільськогосподарські виставки, які часто передували заснуванню музеїв. Завданням таких музеїв було визначити шляхи та напрям розвитку місцевих промислів на традиційній основі, сприяти зростанню продуктивних сил краю. Характерна особливість цих осередків полягала у комплектуванні їх пам'ятками народної культури, у вивченні життя та побуту народу (заняття, промисли та ремесла, народне мистецтво) (Скрипник, 1989: 72).

Міський промисловий музей було організовано Ухвалою 1874 року за ініціативи професора Технічної академії Юліана Захарієвича щодо його заснування за державний кошт і кошти Львівської міської влади. Музей мав на меті зібрати усі пам'ятки художнього промислу, особливо металеві, дерев'яні, текстильні, керамічні та скляні iз найдавніших часів (ЦДІАЛ України. Ф. 735. Оп. 1. Спр. 5. Арк. 29). Окрім міської влади, до розвитку музею долучилися і приватні особи, зокрема львівський історик, письменник та громадський діяч Владислав Лозинський і крайовий маршалок Галичини, політичний діяч і меценат науки Володимир Дідушицький (Matwijów, 2006).

У 1873 році був утворений спеціальний комітет, який підготував статут музеюі почав збирати кошти на його потреби. Як зазначає Л. Федорова (2009), перші пожертви внесли приватні особи - львівський міщанин Ф. Балутовський, князь Л. Сапєга, графи В. Дідушицький і К. Лянцкоронський, а також юридичні особи - управа Львова, Галицька крайова управа, Торгова палата, Галицький іпотечний банк, дирекція залізниці. Для розміщення експозиції музею Міська управа тимчасово виділила будинок Міського стрілецького товариства. 13 травня 1874 року був затверджений перший статут закладу, відповідно до якого справами закладу займалася Надзірна рада, яка обирала зі свого складу виконавчий комітет. Першим головою цього комітету став Ф. Балутовський, його заступником - Л. Вежбицький. Цього ж року відкрилася і перша експозиція музею (Федорова, 2009).

У звіті про стан музею, підготовленому за два роки його функціонування у 1879-1880 роках, наведено вичерпну інформацію про напрями розвитку музею та джерела його фінансування (ЛННБУ ім. В. Стефаника. Ф. 92. Спр. 6). Так, на той час у музеї було зібрано 8538 музейних предметів вартістю 45266 золотих ринських. Збірку складали виставкові предмети (дев'ять груп) усього 6023 вартістю 28 818, 5 з.р.; бібліотечний фонд зі світлинами і картинами олійними фарбами - 1858 предметів вартістю 10 834,93 з.р.; монети, камеї і печатки - 491 одиниця вартістю 402-72 3.p.; мобіляш музеальний у кількості 166 штук вартістю 5210,85 р.з. Загальна кількість предметів музею становила 10000 найменувань. Зазначалося і про недостатні можливості для розміщення предметів, брак приміщень і персоналу (ЛННБУ ім. В. Стефаника. Ф. 92. Спр. 6. Арк. 2).

У документі підкреслюється важливість публічної діяльності музею, його роль у вихованні молоді, що призводило до зростання кількості відвідувачів. Загалом за 1879-1880 роки музей відвідало 7319 відвідувачів, у безкоштовні дні - 6132 (1187 оплатили квитки). Стан і розвиток музею дає змогу зазначити про його вплив у сфері розвитку промислу краю. Для цієї мети керівництво музею запровадило випуск видання «Взори промислу домашнього на Руси», яке мало представити промислові вироби, виготовлені у краї, а також популяризувати музей у Галичині і за кордоном (ЛННБУ ім. В. Стефаника. Ф. 92. Спр. 6. Арк. 5).

У звіті зазначено, що музей не лише у краї, а й за кордоном отримав визнання і позитивні відгуки. Доказом цього $\epsilon$ кореспонденція, яка надходила до закладу із потребою отримання інформації або 3 пропозиціями посередництва у промислових справах. Так, із такою метою зверталася школа гончарства і комітет етнографічної виставки в Коломиї, товариства власності Загребу, управління промислового музею у Берні, дирекція закладу для сиріт у Дрогобичі, дирекція промислової школи Маріано в Істрії (ЛННБУ ім. В. Стефаника. Ф. 92. Спр. 6. Арк. 6).

У документі висловлюється думка, що для підтримки певної тяглості й подальшого розвитку музею має бути вибудувана певна стратегія. Публічність музею забезпечується участю музею у виставковій діяльності у краї та за його межами. Зокрема, музей брав участь у тритижневій виставці у Парижі, на якій також було придбано для музею цінні музейні предмети, які збагатили музейну збірку відділу кераміки й технічні відділи. Для забезпечення публічності музею актуалізувалася потреба видання каталогу, який, окрім переліку музейних предметів, мав містити короткий нарис історичного розвитку відповідних галузей промислу. Враховуючи недостатність історичної літератури з розвитку промислів краю, музей звернувся за необхідною інформацією до Ягелонської бібліотеки, визначних музеїв науки у Варшаві, Петербурзі й інших містах (ЛННБУ ім. В. Стефаника. Ф. 92. Спр. 6. Арк. 6).

Окрім виставкової і просвітницької діяльності, музей впливав на розв'язання проблеми підготовки фахівців для промислової галузі. У звіті про 
стан музею у 1879-1880 роках підкреслювалася важлива роль музею у розвитку промислового шкільництва краю (ЛННБУ ім. В. Стефаника. Ф. 92. Од. зб. 6). У ньому зазначалося, що у приміщенні музею функціонувала школа рисунку моделювання, яка займала велику залу. Незважаючи на те, що це ускладнювало розміщення і систематизацію музейних предметів, актуалізувалося важливе значення школи для розвитку місцевих промислів краю. Наголошувалося на залежності розвитку промисловості від фахової підготовки працівників. Зверталася увага на ії вплив на розвиток промисловості краю і на молодь (ЛННБУ ім. В. Стефаника. Ф. 92. Спр. 6. Арк. 3).

Як свідчить статистика діяльності школи, кількість іiі учнів невпинно зростала. Соціальний склад учнів і учениць представлено середовищем вчителів, ремісників. Заняття у школі відбувалися зранку. У документах справи також порушувалося питання необхідності створення при музеї школи гончарної справи. Ця потреба аргументувалася існуванням у музеї цінної збірки керамічних виробів із краю та із-за кордону для грунтовного навчання фахівців. Тому висловлювалося переконання, що за сприяння музею школа розвиватиметься, готуватиме для краю майстрів, які забезпечуватимуть його продукцією (ЛННБУ ім. В. Стефаника. Ф. 92. Спр. 6. Арк. 4).

Створення музею мало на меті шляхом комплектування і систематизації зразків продукції значної мистецької та наукової цінності сприяти вдосконалюванню у краї технологій виготовлення та естетики промислових і ремісничих виробів (Федорова, 2009: 790). Експозиція музею містила оправу книжок XV століття, металеві вироби (залізні замки, фурнітуру, свічники), меблі, годинники XVI століття, килими та гобелени, польську, саксонську й французьку порцеляну, народну кераміку, церковні пам'ятки, обладнання із Гданська XVII століття, пояси XVIII століття, металеві та дерев'яні вироби Гуцульщини (Matwijów, 2006: 176).

У процесі стрімкого розвитку зі зростанням кількості збірок виникла потреба у відповідному приміщенні. У 1904 році музей отримав власну будівлю на вул. Гетьманській, 20, яка мала зручні умови для розміщення збірок, бібліотеки і читальні, розраховану на більшу кількість відвідувачів. Це забезпечило подальший розвиток музею, що відповідало статусу Львова як столиці краю, спираючись на потреби тогочасної науки. Зацікавлення громадськості в ознайомленні зі збірками зразків художнього промислу, а також бібліотекою зростало, що у 1884 році призвело до потреби зростання штату працівників музею.
Оскільки такий стан не задовольняв тогочасних потреб музею, у 1895 році було запроваджено другу штатну посаду (ЛННБУ ім. В. Стефаника. Ф. 92. Спр. 6. Арк. 29).

Зростання інтересу громадськості й збільшення обсягу роботи працівників музею продемонстровано динамікою відвідування Промислового музею у 1904-1908 роках (ЛННБУ ім. В. Стефаника. Ф. 92. Спр. 6. Арк. 30):

\begin{tabular}{|c|c|c|}
\hline Роки & $\begin{array}{c}\text { Кількість } \\
\text { відвідувачів } \\
\text { музейних збірок }\end{array}$ & $\begin{array}{c}\text { Кількість корис- } \\
\text { тувачів бібліо- } \\
\text { теки }\end{array}$ \\
\hline 1904 & 2759 & 2208 \\
\hline 1905 & 9641 & 4911 \\
\hline 1906 & 10809 & 5968 \\
\hline 1907 & 11871 & 5509 \\
\hline 1908 & 11852 & 6961 \\
\hline
\end{tabular}

Із документів архівної справи 5 можна дізнатися і про роботу читальні музею, яка була відкрита більшу частину року із 9 до 2 год. до обіду та із 5 до 8 год. після обіду у неділю і свята, за винятком дев'яти урочистих. Тому для виконання зазначених вище обов'язків і належного функціонування цієї інституції керівництво музею звернулося до світлого представництва магістрату міста взяти до уваги ухвалу Ради королівського столичного міста Львова щодо збільшення штатних одиниць при Промисловому музеї й встановлення третьої посади службовця 3 відповідним закладенням у бюджет видатків на музей у 1909 році (ЛННБУ ім. В. Стефаника. Ф. 92. Спр. 6. Арк. 30).

$\mathrm{y}$ документах справи також наводиться детальна інформація про функціональні обов'язки працівників музею, які були залучені до роботи бібліотеки й закупівлі збірок: систематичне розміщення й інвентаризацію збірок предметів художнього промислу, які надходять до музею; робота 3 відвідувачами бібліотеки, надання їм фахових послуг, систематизація фондів бібліотеки. Ця робота вимагала від працівників ознайомлення iз новими надходженнями до бібліотеки, науковими працями, листами, рецензіями книг. Серед інших напрямів діяльності музейного персоналу згадується створення тимчасових виставок, співучасть у публічних лекціях. У документі зазначено, що 3 кожним роком збільшувалися й обов'язки адміністрації, які полягали у вирішенні поточних бюрократичних справ, господарському врядуванні будівлі, здійсненні контролю за персоналом, представництві інституції (ЛННБУ ім. В. Стефаника. Ф. 92. Спр. 6. Арк. 30).

Цікаву інформацію містять документи справи і про тогочасне розуміння музейними працівниками 
необхідності вдосконалення професійних якостей працівників, залучених до роботи у бібліотеці і 3 музейними збірками. Зокрема, музейний працівник має бути скрупульозним у закупівлі, розумітися на музейних предметах. На противагу бібліотечній справі, музейна діяльність, окрім фахової кваліфікації, насамперед вимагала від працівника високого рівня особистого горіння, бажання і досвіду, чого можна набути тільки з роками (ЛННБУ ім. В. Стефаника. Ф. 92. Спр. 6. Арк. 29).

Одним із активних організаторів музейної справи в Галичині був Володимир Шухевич відомий етнограф, фольклорист, публіцист, педагог, дід головного командира УПА Романа Шухевича. Починаючи з 1880 року, вчений протягом 10 років був членом Надзірної ради Міського промислового музею, а пізніше - заступником члена виконавчого комітету цього музею.

Майже третину експозиції музею займали зразки українського народного мистецтва, зокрема гуцульського, у набутті якого найбільше допоміг саме В. Шухевич. Він брав участь у підготовці десятитомного видання Промислового музею «Взори домашнього промислу на Руси» (1880-1889), за що дирекція музею висловила йому подяку (Арсенич, 2004: 29). Це видання популяризувало кращі зразки мистецьких виробів із дерева, металу, кераміки, тканини, соломи. Воно стало однією із вдалих спроб дослідження українського народного мистецтва (Скрипник, 1989: 75).

Справи 1-го опису 735-го фонду («Володимир Шухевич - етнограф») Центрального державного історичного архіву України у м. Львові містять детальну інформацію про етнографічну й музейну діяльність В. Шухевича. Як свідчать архівні документи справи 5, 6 грудня 1889 року Рада міста повідомила, що на засіданні 28 листопада 1889 року вона обрала В. Шухевича членом Надзірної ради міського Промислового музею з проханням виконувати належним чином обов'язки цієї ради, окреслені в параграфах 12, 13 Статуту Промислового музею (ЦДІАУ. Ф. 735. Оп. 1. Спр. 5. Арк. 7). 12 січня 1890 року до В. Шухевича звернувся Президент міста Львова Мохнацький, повідомляючи про його обрання на першому засіданні новообраної Надзірної Ради міського Промислового музею заступником члена виконавчого комітету управління музеєм на поточний рік (ЦДІАУ. Ф. 735. Оп. 1. Спр. 5. Арк. 3).

У листі від голови товариства «Просвіта» доктора Омеляна Огоновського від 5 червня 1890 року повідомляється, що на засіданні товариства Просвіта у Львові 4 (16) червня було висловлено щиру подяку Володимиру Шухевичу за заохочення чеського етнографа Франца Ржегоржа, який подарував цінну бібліотеку товариству і доклав зусиль, щоб полегшити іiі передачу (ЦДІАЛ України. Ф. 735. Оп. 1. Спр. 5. Арк. 9). У листі від етнографічного відділу Національного музею Угорщини до В. Шухевича від 15 листопада 1911 року висловлюється прохання прислати предмети, оскільки музей має намір набути колекції усіх сусідніх народів, тому усі предмети, незважаючи на їхню вартість, будуть прийняті з особливою втіхою. Також висловлювалося побажання укласти каталог німецькою й українською мовами (ЦДІАЛ України. Ф. 735. Оп. 1. Спр. 5. Арк. 31).

Важливим науковим доробком музею, як зазначив Г. Скрипник, було видавництво у 1896 році двох збірників під назвою «Художній промисел» і чотирьох окремих випусків «Публікацій із музейних збірок» (1911-1914 років). «Поступово переглядаються основні критерії комплектування колекцій. Якщо на початку колекціонувалися здебільшого зразки західноєвропейського мистецтва, то згодом більше уваги приділялося виробам місцевих народних промислів. Вже на початку першого десятиріччя XX століття біля третини пам'яток експозиції музею відтворювали українське народне мистецтво» (Скрипник, 1989: 75).

У міжвоєнний період музейна збірка налічувала 3724 предмети художнього промислу, 1218 гравюр, літографій, 2723 фотографій, 1731 діапозитив (Muzea gminy miasta Lwowa, 1929). У довідковому виданні "Muzea gminy miasta Lwowa” зазначалося, що вироби польського і світового художнього промислу, які знаходилися у музеї, сягали як різних епох, так і різних матеріалів, зокрема дерева, текстилю, кераміки, скла. На особливу увагу відвідувачів заслуговували керамічні вироби, церковне мистецтво, східні килими, польські ремені, світське та церковне гаптування, оправи книг та народна творчість, репрезентована в різних предметах кераміки, килимах, дерев'яних і металевих виробах, а також у гаптуванні. Бібліотека музею містила 5004 добірні і коштовні праці у 11680 томах із царини здебільшого художнього промислу і мистецтва, якими користувалися численні працівники в музейній читальні (Muzea gminy miasta Lwowa, 1929: 25).

Висновки. Таким чином, здійснений аналіз дав змогу охарактеризувати чинники, які впливали на генезу музейної справи у Львові на зламі XIX $\mathrm{XX}$ ст. З'ясовано значення історичного досвіду становлення і діяльності міського Промислового музею як надбання українського та європейського музейництва, а також роль у його розвитку відомого українського етнографа і громадського діяча 
В. Шухевича. Водночас результати наукового пошуку не вичерпують усього спектру порушеної проблеми, який має бути об’єктом подальшого наукового аналізу.

\section{СПИСОК ВИКОРИСТАНИХ ДЖЕРЕЛ}

1. Арсенич П. Етнографічна і культурно-освітня діяльність Володимира Шухевича. Народна творчість та етнографія. 2004. № 3. С. 15-34.

2. Відділ рукописів ЛННБУ ім. В. Стефаника. Ф. 92 (Райс Л.). Спр. 6 (Міський промисловий музей). 33 арк.

3. Карпенко А. А. Роль Володимира Шухевича в організації українського музейництва в Галичині. Записки історичного факультету. 2015. № 26. С. 85-96.

4. Скрипник Г. А. Етнографічний музей в Україні. К. : Наукова думка, 1989. С. 72.

5. Федорова Л.Д. Львівський міський промисловий музей // Енциклопедія Історії України: т. 6: ла-мі / редкол.: В. А. Смолій (голова) та ін. НАН України, Інститут історії України. К. : Наукова думка, 2009. 790 с. Режим доступу: http://www.history.org.ua/?termin=Lvivsky promysloviy muzey (останній перегляд: 04.04.2020).

6. ЦДІА України у Львові. Ф. 735 (Володимир Шухевич - етнограф). Оп. І, спр. 5.(Шухевич Володимир, український громадський діяч). 38 арк.

7. Шухевич Володимир // ЛННБУ ім. В. Стефаника. Відділ рукописів. Ф. 167 (Левицький І.), оп. II, од. зб. 3470, арк. 28-30.

8. Matwijów M. Muzea lwowskie wczoraj i dziś. Niepodległość i pamięć. 2006. № 13/3 (24). S. 175-196.

9. Muzea gminy miasta Lwowa 1929 r. Muzea gminy miasta Lwowa 1929 r.

\section{REFERENCES}

1. Arsenych P. (2004). Etnohrafichna i kulturno-osvitnya diyalnist Volodymyra Shuchevycha. [Ethnographic and cultural-educational activity of Volodymyr Shuchevych]. Folk art and ethnography, № 3, p. 15-34 [in Ukrainian].

2. Viddil rukopysiv LNNBU im. V. Stefanyka. [Manuscripts department of the Lviv National Scientific Library named after V. Stefanyk]. Stock 92. Case 6. Miskyj Promyslovyj Muzey. [City Industrial Museum]. Pages 33 [in Ukrainian].

3. Karpenko A. A. (2015). Rol Volodymyra Shuchevycha v orhanizaciyi ukrayinskoho muzejnyctva v Halychyni. [The role of Volodymyr Shuchevych in the organization of Ukrainian museology in Galicia]. Notes of the History Faculty, № 26, p. 85-96 [in Ukrainian].

4. Skrypnyk H. A. (1989). Etnohrafichnyj muzej v Ukrayini. [Ethnographic museum in Ukraine]. Kyiv : Scientific thought, p. 72 [in Ukrainian].

5. Fedorova L. D. (2009). Lvivskyj miskyj promyslovyj muzej. [Lviv city industrial museum]. Kyiv : Encyclopedia of the history of Ukraine, ed board Smoliy (head) and others of the NAS of Ukraine, Institute of the history of Ukraine. Scientific thought, p. 790. Retrieved through: http://www.history.org.ua/?termin=Lvivsky promysloviy muzey [in Ukrainian].

6. ZDIA Ukrainy u Lvovi [Central National Historic Archive in Lviv]. $\overline{\mathrm{F}} 735$. Volodymyr Shuchevych - etnohraf, Descr. 1, Case 5, Shuchevych Volodymyr, ukrayinskyj hromadskyj diyach [Shuchevych Volodymyr, Ukrainian social activist]. P. 38 [in Ukrainian].

7. Shuchevych Volodymyr. LNNBU im Stefanyka. [Lviv National Regional Library named after V. Stefanyk]. Department of Manuskripts, F 167, od. zb 3470, p. 28-30 [in Ukrainian].

8. Matwijów M. (2006). Muzea lwowskie wczoraj i dziś. Niepodległość i pamięć. № 13/3 (24). P. $175-196$ [in Polnish].

9. Muzea gminy miasta Lwowa (1929). Muzea gminy miasta Lwowa 1929 r [in Polnish]. 